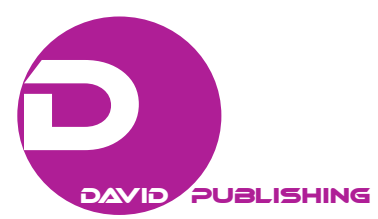

\title{
Reporting on Land as Natural Capital by Gold Mining Houses in South Africa
}

\author{
Anet Smit, TK Bungane \\ North-West University, Potchefstroom, South Africa
}

\begin{abstract}
Motivated by the increasing popularity and advocating for integrated reporting by companies on their operations, the aim of this paper is to determine the disclosure levels on land by mining houses in South Africa in their integrated reports. Developing countries, such as South Africa should ensure sustainability of their natural resources in their endeavour of growing their economies. The mining sector in South Africa is a huge contributor to the economy, but also has a significant impact on land conservation. The complexity of mining activities and impacts thereof make it challenging for organisations to disclose information on land. This paper is descriptive by design; it contains a literature review, followed by a content analysis of the mining houses integrated reports by using a checklist. The checklist was based on recommendations by the Global Reporting Initiative (GRI) guidelines as to what the content of the integrated report on land should be. Fourteen mining houses operating in South Africa and registered on the Johannesburg Stock Exchange (JSE) were identified and analysed for this study. The findings of the paper display low levels of overall disclosure on land by the South African mining companies. However, there were high levels of disclosure for EN11, EN12, and MM1 sector-specific supplement in the integrated reports. Low levels of disclosure by the mining companies were evident in MM2 the sector-specific recommendations as well as the physical and monetary information related to MM2.
\end{abstract}

Keywords: natural capital, environmental impact, land, mining, Global Reporting Initiative 4, integrated reporting

\section{Introduction}

It is essential to ensure sustainability while saving the environment, especially as this is one of the challenges in developing countries. Szekely and Knirsch (2005) stated that the main challenge to mankind in the 21 st century is building a sustainable society, without degrading the natural resources at an increasing rate. They further argued that impacts on the environment, such as depletion of natural resources and degradation of land are not included in the long-term environmental impact assessments of organisations. The assessments of economic and environmental performance of organisations are not reported accurately, leading to organisations not being sustainable in the long run (Bonner et al., 2012).

The mining industry, according to Constanza and Daly (2002), is more dependent on natural resources and natural capital than any other industry. Maxwell, Mckenzie, and Traldi (2014) emphasised that for

Anet Smit, Ph.D., professor in Management Accounting, NWU Business School, North-West University, Potchefstroom, South Africa.

TK Bungane, MBA student at NWU Business School, North-West University, Potchefstroom, South Africa.

Correspondence concerning this article should be addressed to Anet Smit, NWU Business School, North-West University, Potchefstroom 2531, South Africa. 
organisations to be sustainable and valuable in the long run, they should maintain the ecosystems and resources they are dependent on. Houdet and Germaneau (2011) highlighted that businesses and government leaders around the globe are increasing their attention to the need for effective management of business dependencies and impacts on the ecosystem. Global business leaders have advocated for the integration of natural capital considerations in their decision-making process and financial reporting (Bonner et al., 2012).

Goodwin (2003) reasoned that natural capital is not always restored once degraded and when it is depleted either in quality or quantity, the positive inflow of benefits from the natural capital are lost. Natural capital is environmental assets from which beneficial services flow into the economy (PostNote, 2011). Bonner et al. (2012) agreed that it is difficult to put a value and to report on natural resources. Ecosystem services valuation frameworks have been recommended as basis for accounting and reporting on natural capital. Van Zyl (2013) stated that in service provision and or in goods production, natural capital is often an input and that institutions can impact positively or negatively on this capital.

The International Integrated Reporting Committee mentioned that natural resources should not be depleted, but companies need to be accountable for how they utilise its natural capital as it provides the environment in which the other capitals fit (IIRC, 2013). According to the Corporate Eco forum (2012), in the past, natural capital has been excluded in business decision-making and market transactions because it is difficult to monetarise the value of natural capital. Maxwell et al. (2014) pointed out that economists have developed a number of techniques to value natural capital.

Reporting on natural capital is commonly done in the sustainability report. Permitting to Ioannou and Serafeim (2014), there has been an increase in sustainability reporting, and they advocate this trend to the increasing number of regulations that are emerging in global economics. These regulations are mandating firms to disclose on governance, environmental, and social information. Houdet and Germaneau (2011) added that even though organisations are reporting on sustainability, sustainability reporting is falling short in providing the relevant stakeholders of organisations with detailed sustainability information to enhance their decision-making. Bishop (2010) highlighted that many organisations, practitioners, and academics have identified the need for an improvement in the reporting on natural capital. Most organisations are dependent on land for their operations and production; however, land is unaccounted for and less or no reporting is done on it in the integrated report (J. F. Solomon \& A. Solomon, 2006).

Elliott (2004) argued that the environmental and social costs of production are not fully reflected in the current accounting and economic models. Elliot (2004) stated that corporate activities, regardless of the efficiency levels, have a direct and indirect effect on the environment through pollution and environmental service exploitation and also identify the gap due to inadequate reporting on land in accordance with the Global Reporting Initiative (GRI).

Based on the discussions in the introduction, the following questions can be asked: Do mining organisations disclose on environmental issues? Do mining organisations report and disclose information on land? What elements do organisations disclose on pertaining to land within their sustainability context? To answer these questions, the main objective of the study is to assess the adequacy of reporting on land within the context of South African mining houses in their integrated reports. A possible limitation of the study is that it excludes companies not listed on Johannesburg Stock Exchange (JSE) and therefore does not reflect a comprehensive picture of the levels of land disclosure. 


\section{Background and Literature Review}

\section{Sustainability Reporting}

According to Szekely and Knirsch (2005), there are various approaches to measure and report on sustainability performances, but none of these approaches have been adopted as the universal tool for all industries. Conferring to PricewaterhouseCoopers ( $\mathrm{PwC}$, 2013), a recent trend shows that stakeholders are increasingly putting pressure on organisations to disclose on their environmental, social, and governance information. Internal decision-makers within organisations, including public authorities, are finding it challenging to link non-financial and financial information to economic variables and are lacking sustainability information (Betianu \& Briciu, 2010). The Association of Certified Chartered Accountants (ACCA, 2014) agreed to a positive trend to stimulate the integration of environmental and social aspects of business in reporting.

\section{Quality of Reporting}

Ernest and Young (2013) stated that a good report should include the informative information on material issues; it should be relevant and on time. The GRI (2011) put forward some principles that ensure good reporting, meaning that a good report should follow or adhere to the principles of inclusiveness and transparency. Through the reports the organisation's performance can be presented within the broader context of sustainability challenges, risks, and opportunities (IoDSA, 2011). The reported information should pass the completeness test in terms of reporting boundaries, scope, and timeframe. Lastly, reported information should be relevant to the decision-making needs of stakeholders. The report reliability and quality are ensured by the principles of accuracy, comparability, and neutrality.

The aspects of accountability and reporting in the mining industry of their activities on the environment they operate in, have presented challenges to the mining houses and their stakeholders. Failure to establish a standard reporting framework across all industries has led to the failure to hold firms accountable for their environmental impacts (Eccles \& Armbrester, 2011, p. 15). Good reporting should ensure that firms are working towards sustainable development, and Brundtland Report (1987) defined sustainable development as development that delivers the needs of the present whilst ensuring that the coming generations will have the capability of meeting their needs. The following hurdles to all-inclusive disclosures on biodiversity and ecosystem services (BES) were highlighted by the Economics of Ecosystems and Biodiversity (TEEB) for Business Report (Trucost, 2013):

- To identify material aspects as part of the business;

- To identify potential links between business risk, opportunity, and natural capital and, therefore, the need to manage and monitor them is overlooked;

- The lack of disclosure guidelines and valuation methodologies;

- Concern was expressed that the overall credibility of the annual report might be undermined by the potentially large error margins in calculating BES indicators.

Stakeholders are becoming increasingly engaged with these issues as mentioned above. In trying to encourage the sustainable use of biodiversity and ecosystem services (BES), governments are exploring policy or regulatory changes through the development of national ecosystem services accounting frameworks (Deloitte, 2012). To address the gap between investors' requirements for more comprehensive information and what is presently being reported, corporations need to evolve their reporting (ACCA, 2014). It is clear that with the 
current reporting practice, a shift is needed towards a standardised reporting framework, which will incorporate the non-financial and financial elements of the institution.

Integrated Reporting provides a basis to address this by re-focusing reporting around an organisation's business model and operational priorities. The aim is to reflect the critical opportunities and challenges that affect the business; the same issues that management are dealing with on a daily basis within the organisation. (Ernest and Young, 2013)

\section{Integrated Reporting}

The International Integrated Reporting Committee (IIRC, 2011) defined integrated reporting as a report that brings together material information about an organisation's strategy, governance, performance, and prospects. The IIRC further highlighted that integrated reporting is intended to provide a clear and concise representation of how an organisation creates value, now and in the future. According to PricewaterhouseCoopers ( $\mathrm{PwC}, 2013)$, integrated reporting is defined as "a process that results in communication by an organisation, most visibly periodic integrated report, about how an organisation's strategy, governance, performance and prospects lead to the creating of value over the short, medium and long-term".

The Johannesburg Stock Exchange (JSE) has mandated the disclosure on sustainability in integrated reporting, starting 2010, and King III stated that reporting on sustainability issues has to be linked with financial reporting and that sustainability issues should be independently assured (Ioannou \& Serafeim, 2014). The main output of integrated reporting is an integrated report, a solo report that is meant to replace the current requirements and to become the primary report for an organisation (GRI, 2011).

With the release of integrated reporting (IR) guidelines by the Integrated Reporting Committee of South Africa (IRC of SA, 2011), the International Integrated Reporting Committee (IIRC, 2013) and the Accounting Standards set by International Financial Reporting Standards (IFRS), there has been observed improvement in reporting in South Africa (Ernst \& Young, 2013). Integrated reporting combines financial and non-financial information with a forward-looking perspective that is designed to help readers understand all the components of business value and how they may be affected by future opportunities and exposures to risk (Ernst \& Young, 2013; Visser, 2011). The integrated reporting method or framework presents more benefits, especially with regard to integrated thinking and decision-making in terms of risks, costs, capital, environment, social and economic performance of the organisation, and disclosures to the organisations stakeholders (Eccles \& Armbrester, 2011). The Integrated Reporting Committee of South Africa (IRC of SA, 2011) highlighted that it is clear that the successes and/or failures of organisations are dependent on organisations creating and sustaining value without depleting the natural capital assets. Figure 1 is an integrated reporting framework that shows the interconnections among the different organisational aspects and information that should be considered or included in compiling an integrated report.

Full adoption of integrated reporting is a journey and it could take most companies up to three years to become totally familiar to this way of reporting (Fisher-Kowalski, 2011). Guiding principles for integrated reporting are the following: strategic focus, future orientation, responsiveness and stakeholder inclusiveness, conciseness, reliability, and materiality (Gray, 2012). South Africa is among the few countries in the world that is at the fore front in integrated reporting (Deloitte, 2012).

\section{The Six Capitals}

According to Ernst and Young (2013), there is an evident trend of firms around the world trying to include or disclose on all the six capitals in their integrated reports, and this is because there is an interconnections 
between these capitals. Figure 2 shows these interconnections of the capitals in an organisation's operations point of view and shows how organisations are dependent on the six capitals for their existence. This argument is assisted by Eccles and Krzus (2010) and KPMG (2012) that a firms' dependency on natural resources or natural capital requires that organisations disclose on their impact on these resources.

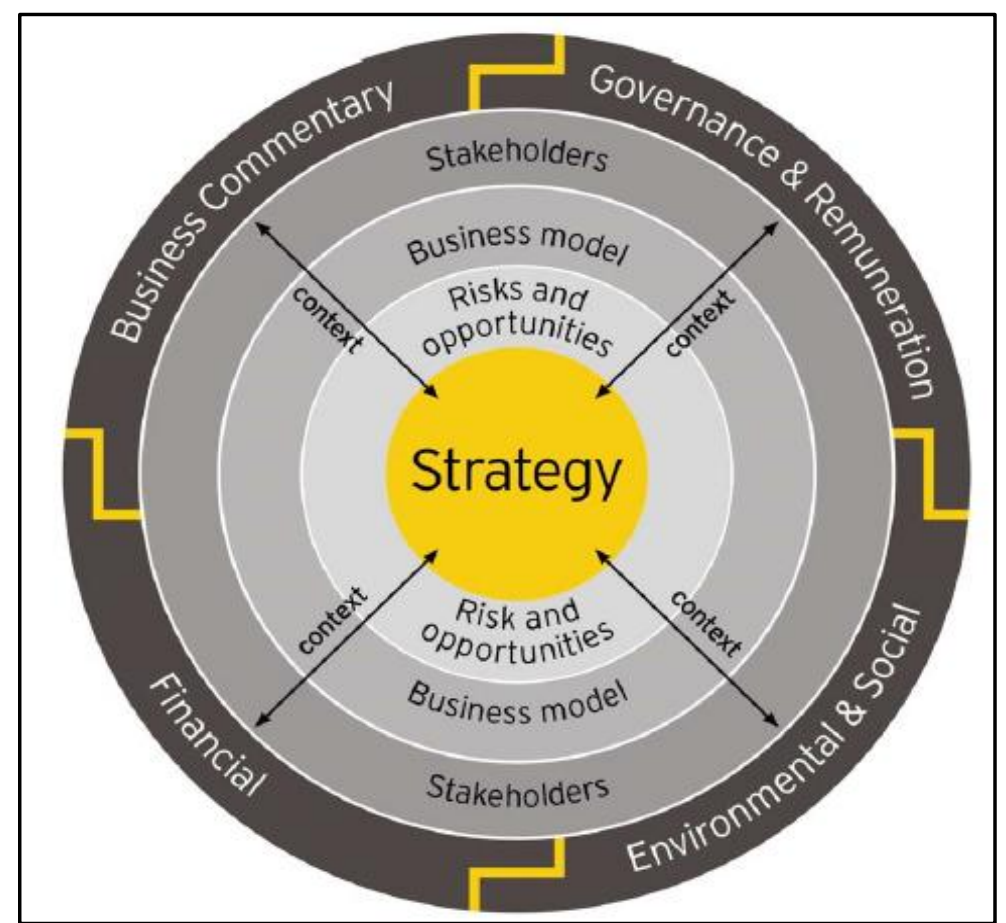

Figure 1. Updated integrated report framework (Source: Deloitte, 2016, p. 12).



Figure 2. The six capitals prototype framework (Source: AccountAbility, 2013, p. 17). 


\section{Natural Capital}

The Natural Capital Declaration (NCD, 2013) highlighted that the Natural Capital Declaration was a financial-led initiative by businesses to integrate natural capital in their reporting. This is to ensure that natural capital is considered into financial products and services as part of financial reporting and disclosure. A large body of work has applied the capital approach to sustainability to assess whether different types of capital are substitutable and whether critical natural capital exists (Ekins, 2001).

A definition often used to describe natural capital is that technically, natural capital is the stock of natural ecosystems that yields a flow of valuable ecosystem goods or services (TEEB, 2010). Similarly, the organisation for Economic Co-operation and Development (OECD, 2007) defined natural capital as "the natural assets in their role of providing natural resource inputs and environmental services for economic production". Natural capital includes air, water, land, forests, materials, minerals, energy, and biodiversity and ecosystem health. Related aspects include emissions, effluents, and waste (Ernst \& Young, 2013; Brand, 2009).

As more awareness is being raised by governments, institutions such as the United Nations, the Global Reporting Initiative and various others, disclosure on natural capital has gained momentum. Legal entities to protect the environment have been established and companies could expect to be under investigation on how they protect the natural resources for example if they need to get permission to develop a mine as a result of the potential significant impacts on agriculture, forests, and endangered species.

The problem we face is that natural capital has been harvested or degraded at a rate that threatens to undermine both well-being and future economic growth due to overreliance on the natural resources (United Nations Environment Programme [UNEP], 2016). AccountAbility (2013) and ACCA, Flora \& Fauna International (FFI), and Klynveld Peat Marwick Goerdeler (KPMG) (2012) argued that some companies have direct impacts or dependencies on natural capital (such as forestry companies), while others (such as retailers) have indirect impacts or dependencies on natural capital. The accounting profession faces the challenge of identifying the time or point where the loss of natural capital will necessitate an improved approach to business-risk assessment and understands the importance of corporate disclosure. Delaying this will reduce the capabilities to anticipate future business cost associated with future risks (AccountAbility, 2013). The most important barrier to the integration of natural capital into accounting is the lack of accepted standards for its measurement and valuation. Harmonised methods are, however, necessary for a consistent recording of the data, which determines the comparability of the results. The effects along the supply chain, in particular, remain a major challenge (JSE, 2011).

\section{Materiality and Natural Capital Issues}

AcountAbility (2013) defined material issues as those issues that could influence the user of financial accounts. Key stakeholders, such as investors, still largely judge corporate performance on the basis of measures of financial materiality. Many environmental and social issues are rarely considered to be material by companies, despite increasing concern from civil society. The concept of materiality underlies principles of corporate disclosure. Unless the materiality of BES as an issue can be demonstrated, the arguments for its inclusion within corporate disclosures, and by association corporate strategy and management systems, are weak (AcountAbility, 2013; Deloitte, 2012). However, if a broad definition of materiality is followed that includes consideration of stakeholder views (investors, communities, civil society, and government) and longer-term business, BES issues are more likely to be considered material, enabling companies to consider an 
emerging set of risks and opportunities (Trucost, 2013).

\section{Reporting on Natural Capital}

According to AccountAbility(2013), reporting on natural capital can be split into two main categories, narrative reporting on strategy and management, and performance reporting. The former provides stakeholders with a qualitative understanding of the organisation's relationship with natural capital and the processes used to manage the various risks and opportunities associated with the organisation's activities. Performance reporting uses performance indicators (KPIs) that track performance over time to provide stakeholders with quantitative information (AccountAbility, 2013). Land is one of the major BES elements that is utilised most by the mining industry in South Africa. According to the GRI 4 guidelines (EN11), land refers to the location and size of land owned, leased, managed in, or adjacent to, protected areas and areas of high biodiversity value outside protected areas.

According to International Council on Mining and Metals (ICMM, 2006), mining has the potential to impact biodiversity throughout the lifecycle of a project, both directly and indirectly. Direct or primary impacts from mining can result from any activity that involves land clearance (e.g., access road construction, exploration drilling, overburden stripping, and tailings impoundment construction) or direct discharges to water bodies (e.g., riverine tailings disposal and tailings impoundment releases), and are usually readily identifiable. Indirect or secondary impacts can result from social or environmental changes brought about by mining operations that are often harder to identify immediately.

\section{Frameworks that Assist Reporting}

Governments, non-governmental organizations (NGO's) and industry bodies have developed a range of frameworks or guidelines to assist companies in identifying and disclosing their environmental and social performance (Glazewski, 2005). Kotzé (2009) argued that although these are not statutory requirements, they are increasingly being adopted by the private sector. Cross-sectoral guidance produced by the GRI is perhaps the most widely used guidance for corporate reporting. Organisations in South Africa need to meet their regulatory reporting requirements under King III, the Companies Act of 2008, International Financial Reporting Standards and the JSE-listing requirements. They may also wish to subscribe to certain non-mandatory frameworks, such as the Global Reporting Initiative, JSE Socially Responsible Index, Carbon Disclosure Project, United Nations Global Compact, and Millennium Development Goals (Van Zyl, 2013).

The Global Reporting Initiative (GRI) is a non-profit organisation that has established the most generally applied sustainability reporting frameworks. In May 2013, GRI launched the fourth generation (G4) of its standards. In addition to its reporting framework, GRI has produced specific guidance detailing approaches for reporting on ecosystem services. GRI (closely connected with the IIRC) describes its mission as "to make sustainability reporting standard practice for all organisations.

\section{GRI and Land}

The GRI classifies land and land issues in accordance with the following indicators, EN11, EN12, MM1, and MM2 to be used as guidelines to report on land. EN refers to the environmental category in the GRI and under the aspect of biodiversity, EN 11 and EN 12 deal with land issues. This research will focus on disclosure items related to the operation of the mining houses in South Africa and therefore the Mining and Minerals Supplements MM1 and MM2 are added. Below, these items are explained and defined as set out in the GRI guidelines. 


\section{EN11 Disclosure on Land of Each Operational Site}

Disclosure on land in the integrated report, according to EN11, should include information on each operation site owned, leased, managed in, or adjacent to protected areas and areas of high biodiversity value outside protected areas. Information with regard to the above should be disclosed in the integrated report to include the following dimensions:

Geographic location. Organisations should clearly disclose their location; this will be where the organisation operates in and/or plans to operate in the future. This will enable stakeholders to assess the direct and indirect impacts of the organisation on the areas occupied or in surrounding areas.

Subsurface and underground land. It may be owned, leased, or managed by the organisation: Disclosure on whether the land owned or occupied is underground or surface. This helps stakeholders in judging whether the information disclosed by organisations is material with regard to the operations of the organisation.

Position in relation to the protected area (in the area, adjacent to, or containing portions of the protected area) or the high biodiversity value area outside protected areas: The disclosure of the above also helps and perceives the nature of impact the organisation has on the protected areas either direct or indirect.

Type of operation (office, manufacturing or production, or extractive). The disclosure of the type of operations the organisation carries on the occupied land will help to assess the nature of impacts the organisation might be having on the environment and to judge whether the management and/or rehabilitation procedures are set in place if they are relevant.

Size of operational site in $\mathbf{k m 2}$. This is one of the most important disclosures that the organisation has to disclose on land; this will be with regard to elements such as budgets for rehabilitation and accountability into the impacts cause on the land. It is assumed that the higher the land in square kilometre $(\mathrm{km} 2)$ occupied by the organisation for its operation the higher the impacts on land either direct or indirect.

Biodiversity value characterised by: The attribute of the protected area or high biodiversity value area outside the protected area (terrestrial, freshwater, or maritime ecosystem): This will indicate the awareness of the organisation on their surrounding areas and the impact they might have. Once organisations disclose that they are aware of the high biodiversity value areas outside the protected areas, it can be assumed that they will take action or put plans in place to minimise their impacts on these areas.

Listing of protected status (such as IUCN Protected Area Management Categories, Ramsar Convention, and national legislation).

\section{EN12: Disclosure of Impact on Land}

When referring to EN12, organisations have to disclose in their integrated reports a detailed description of significant impacts of activities, products, and services on biodiversity in protected areas and areas of high biodiversity value outside protected areas. The disclosure by organisations should reflect the two dimensions as discussed below:

Organisations need to disclose on the nature of their direct and indirect impacts on land with reference to one or more of the following:

Change in land scope for transport and manufacturing infrastructure, Pollutants added, foreign pests, pathogens and invasive species added, Introduction of invasive species, pests and pathogens, Species reduction, Conversion of habitat, Changes in ecological processes outside the natural range of variation (such as salinity or changes in groundwater level).

Organisations, when disclosing, should expand their disclosure on land to cover the significant direct and 
indirect positive and negative impacts with reference to the following: "Irreversibility or reversibility of the impacts, Magnitude of impacted areas, Impacts Duration and Species affected".

Below are the sector specific supplements that deal with land issues in the mining sector.

\section{Mining and Minerals (MM1) Supplement and Land}

The MM1 sector-specific supplement for the mining and minerals industry, according to the G4, should ensure inclusion of certain material issues in their disclosure based on the sector-specific supplement code under the G4-MM1. The sector-specific supplement for the mining industry emphasises that mining organisations should be specific and concentrate on the land (owned or leased, and managed for production activities or extractive use) disturbed or rehabilitated in their disclosure.

\section{MM2: Sector-Specific Supplement}

The MM2 sector-specific supplement for the mining industry can be linked to the G4-EN12, as it advocates that organisations should disclose the number and percentage of total sites that they have identified as "requiring biodiversity management plans", and the number and/or percentage of those sites with plans in place. This disclosure will show that organisations are taking accountability for their indirect and direct impacts on the environment. As part of this disclosure physical and monetary information should be added.

\section{Physical Information on Land Issues}

The physical information on land-related issues per square kilometre $(\mathrm{km} \mathrm{2})$ of land will be information on land disturbed by the operations of the mining houses, plans for management of this land under occupation by the mines, and the amount of land in $\mathrm{km} \mathrm{2.} \mathrm{Information} \mathrm{includes} \mathrm{the} \mathrm{km} 2$ of land under rehabilitation by the mining houses and future $\mathrm{km} 2$ of land the mining is planning to rehabilitate. It is important for organisations to disclose this information in their reporting on land and the impacts of their activities and accountability when it comes to the land they occupy.

\section{Monetary Information on Land Issues}

The monetary information on land refers to the budgets and/or expenditure that has been directed on land; it can be either for land management and/or rehabilitation. Furthermore, it can include the opportunity costs or future cost associated with future spending on land. It is important that this information is disclosed as it will show the shareholders how much costs the organisations have outside their production frontier and also helps the communities and governing bodies in costing the impacts of organisations and to see whether the investments made by organisation in maintaining and restoring land are justifiable.

In reference to the National Environment Management: Protected Areas Act (No. 57 of 2003), the GRI 4-EN11, EN12, and King III, it is of most prominence for the mining companies to monitor and report its impact on land as part of natural capital.

\section{Research Methodology}

This research is descriptive by design and involves a literature review, followed by a content analysis of the mining houses integrated reports using a checklist. The checklist was compiled and constructed by the researcher based on the literature. This study targeted mining houses that are listed on the JSE and operating in South Africa. The integrated reports selected for the study were the ones for 2014 to 2015 because the analysis was based on the GRI 4 guidelines published in 2013. The content analysis checklist was constructed in such a way that it consisted of five sub-sections, namely, EN11, EN12, MM1, and MM2 that includes the physical and 
monetary information. Data were collected by downloading 2014 and 2015 integrated reports of the JSE-listed companies from their websites. The checklist instrument was scored for each applicable disclosure in the section analysed in accordance with the criteria. The data on the checklist of each mining house were summarised on the disclosure datasheet, then entered into the Excel spreadsheet and analysed. If an item of information is either not disclosed at all or its disclosure lacks sufficiency or its nondisclosure is not justified, the item is scored as No (0). If a piece of information is disclosed properly in the relevant sections of the annual report with sufficient details or its nondisclosure is justified, the item is scored as Yes (1). The results from the analysis are discussed and presented using graphs and tables.

\section{Research Findings}

\section{Overall Disclosure by the Mining Companies}

The objective of the empirical analysis was to assess the overall disclosure by the companies on all the aspects on land in the integrated reports and also disclosure of sector-specific aspects under the sector supplements as per the GRI guidelines.

Table 1

\section{Overall Disclosure}

\begin{tabular}{llc}
\hline Items & Yes (\%) & No (\%) \\
\hline EN11(operation site owned, leased or managed) (six items) & 82 & 18 \\
EN12(disclosure of significant impact on land) (nine items) & 62 & 38 \\
Sector-specific (MM1) (refers to the land disturbed by the mining operations) (one item) & 79 & 21 \\
Sector-specific (MM2) (the number of sites with requires biodiversity management plans (BMP) & 43 & 57 \\
(one item) & 43 & 57 \\
(MM2)Physical information (one item) & 36 & 64 \\
(MM2) Monetary information (one item) & 57.5 & 42.5 \\
Overall a total of 19 items & & \\
\hline
\end{tabular}

The checklist had 19 land information items to assess for disclosure for each of the top 14 mining companies used in the study, which results in 266 land information items to be assessed in the period covered by the study. As per Table 1, the level of overall disclosure on land-related information by the mining houses in their integrated reports was $57.5 \%$.

Further investigation of the overall quality of land disclosure by each item in Table 1 reveals the three best disclosed aspects, as EN11, 82\% disclose information about the site, EN12, 62\% disclose information regarding biodiversity management plans; and sector-specific aspects (MM1), 79\% disclose information about land disturbed by mining operations.

With only $57.5 \%$ overall disclosure on land issues by the mining companies, this disclosure level is moderately low. This low disclosure level is as a result of three of the aspects having disclosure levels below average, namely, the sector-specific MM2, physical and monetary information. The results confirm the link between the three, as sector-specific MM2 stipulates that mining companies should disclose information on the "number and percentage of sites identified as requiring biodiversity management plans (BMP) and those having plans in place". If the companies did not disclose on MM2, it resulted in less disclosure of physical and monetary information. The other three aspects having disclosure levels above average also have a similar link among them. More detail on the six items that are part of EN11 will be discussed in more detail in the sections below. 


\section{EN11 (Operation Site Owned, Leased, or Managed)}

EN11 addresses the disclosure with respect to "operations sites owned, leased, managed, or adjacent to protected areas and areas of high biodiversity value outside protected areas". EN 11 contains six items that will be discussed separately. According to Table 1, the overall level of disclosure on EN11 (operation site owned, leased, or managed) was $82 \%$ and Table 2 provides detail per sub headings.

Table 2

EN11 (Operation Site Owned, Leased, or Managed)

\begin{tabular}{|c|c|c|c|c|c|}
\hline & Items & Yes & $\%$ & No & $\%$ \\
\hline 1 & Geographic location & 14 & 100 & 0 & 0 \\
\hline 2 & Subsurface and underground land that may be owned, leased, or managed by the organisation & 14 & 100 & 0 & 0 \\
\hline 3 & $\begin{array}{l}\text { Position in relation to the protected area (in the area, adjacent to, or containing portions of the } \\
\text { protected area) or the high biodiversity value area outside protected areas. }\end{array}$ & 9 & 64 & 5 & 36 \\
\hline 4 & Type of operation (office, manufacturing or production, or extractive). & 9 & 64 & 5 & 36 \\
\hline 5 & Size of operational site in $\mathrm{km} 2$ & 12 & 86 & 2 & 14 \\
\hline 6 & $\begin{array}{l}\text { Biodiversity value characterised by: The attribute of the protected area or high biodiversity } \\
\text { value area outside the protected area. }\end{array}$ & 11 & 79 & 3 & 21 \\
\hline
\end{tabular}

A more detailed analysis of disclosure on the different biodiversity items in Table 2 shows significant differences in disclosure levels with aspects, such as geographic locations and surface-underground operations having $100 \%$ disclosure and position of operation site in relation to protected areas and type of operation having $64 \%$. The remaining items were disclosed above average in the mining houses' integrated reports.

\section{EN12 (Description of Significant Impact on Land)}

EN12 deals with "descriptions of impacts of activities, products, and services on biodiversity in protected areas and areas of high biodiversity value outside protected areas". Table 1 shows that the overall disclosure level on EN12, describing the impact of mining activities on land was $62 \%$. Table 3 provides the detailed analysis of each item under this category

Table 3

EN12 (Description of Significant Impact on Land)

\begin{tabular}{|c|c|c|c|c|c|}
\hline & Items & Yes & $\%$ & No & $\%$ \\
\hline 1 & Construction or use of manufacturing plants, mines, and transport infrastructure & 14 & 100 & 0 & 0 \\
\hline 2 & $\begin{array}{l}\text { Pollution (introduction of substances that do not naturally occur in the habitat from point } \\
\text { and non-point sources) }\end{array}$ & 13 & 93 & 1 & 7 \\
\hline 3 & Introduction of invasive species, pests, and pathogen & 9 & 64 & 5 & 36 \\
\hline 4 & Reduction of species & 10 & 71 & 4 & 19 \\
\hline 5 & Habitat conversion & 10 & 71 & 4 & 19 \\
\hline 6 & $\begin{array}{l}\text { Changes in ecological processes outside the natural range of variation (such as salinity or } \\
\text { changes in groundwater level) }\end{array}$ & 7 & 50 & 7 & 50 \\
\hline 7 & Species affected & 3 & 21 & 11 & 79 \\
\hline 8 & Extent of areas impacted & 7 & 50 & 7 & 50 \\
\hline 9 & Duration of impacts & 3 & 21 & 11 & 79 \\
\hline
\end{tabular}

The item with the highest percentage of disclosure were the description about the use of manufacturing plants (100\%) and in the second place more detail about the pollution caused on the land (93\%). Two items with the lowest percentage of disclosure, both having $21 \%$, were detail on the duration of the impact on the 
land and information on species affected by the mining operations. The average disclosure level on EN12 of $62 \%$ indicates that most of the mining houses are disclosing on the impacts of activities, products and services on biodiversity in protected areas and areas of high biodiversity value outside the protected areas.

\section{Sector-Specific MM1 (Amount of Land Disturbed by Mining Operations)}

The objective of analysing MM1 was to evaluate the level of disclosure by the mining houses on the amount of land owned or leased, and managed for production activities or extractive use, disturbed or rehabilitated. As this item is part of the mining and minerals sector-specific supplement, it emphasises that mining houses should disclose accurate information on the land they have disturbed throughout their operations and the amount of land they have rehabilitated. Table 1 indicates the overall disclosure of this item was $79 \%$. This provides an indication that mining houses report above average on information about the amount of land affected or to be rehabilitated by the mining operations.

\section{MM2 (The Number of Sites That Need Biodiversity Management Plans)}

The objective of this section was to assess whether organisations were taking accountability for their indirect and direct impacts on the environment. This aspect stipulates that organisations should "disclose the number and percentage of total sites that they have identified as requiring biodiversity management plans, and the number and/or percentage of those sites with plans in place". The results of the overall disclosure level for this aspect are shown in Table 4.

Table 4

MM2 (The Number of Sites That Need Biodiversity Management Plans)

\begin{tabular}{|c|c|c|c|c|c|}
\hline & Item & Yes & $\%$ & No & $\%$ \\
\hline 1. & $\begin{array}{l}\text { The number and percentage of total sites identified as requiring } \\
\text { biodiversity management plans, and the number (percentage) of } \\
\text { those sites with plans in place }\end{array}$ & 6 & 43 & 8 & 57 \\
\hline
\end{tabular}

According to Table 4, the overall disclosure level of sector-specific MM2 by the mining companies was at a low 43\%. This below average disclosure indicates that the mining houses do not provide for biodiversity management plans on the sites. As part of the disclosure of MM2, it is the required information concerning physical and monetary site information. Physical information refers to information on land per $\mathrm{km} 2$ with regard to disturbance, management, and rehabilitation plans. Organisations should disclose in $\mathrm{km} 2$ on the amount of land under their ownership, leased or adjacent to their operations that has been disturbed, managed, and/or rehabilitated.

The disclosure of monetary information on land refers to the budgets and/or expenditure that has been directed to land and it can be either for land management and/or rehabilitation. Furthermore, it can include the opportunity costs or future cost associated with future spending on land. Table 5 indicates the disclosure of physical and monetary information.

Table 5

Physical and monetary information on land

\begin{tabular}{|c|c|c|c|c|c|}
\hline & Items & Yes & $\%$ & No & $\%$ \\
\hline 1. & $\begin{array}{l}\text { Physical Information: Information on land per } \mathrm{km} 2 \text { with regard to } \\
\text { disturbance, management and rehabilitation. }\end{array}$ & 6 & 43 & 8 & 57 \\
\hline 2. & $\begin{array}{l}\text { Monetary information: Information on budgets or expenditure on land } \\
\text { management, rehabilitation and also on the cost of disturbance }\end{array}$ & 5 & 36 & 9 & 64 \\
\hline
\end{tabular}


According to Table 5, the level of disclosure on physical information on land disturbed, managed, and under rehabilitation was low at around 43\%, with only six of the 14 mining houses disclose information. Thus, it failed to disclose quantified information in $\mathrm{km} 2$ on land with regard to disturbance, management, and rehabilitation. This is in contrast to the GRI principles of transparent and quality disclosure of information in integrated reports.

According to Table 5, the level of disclosure on monetary information with regard to land is also low, at $36 \%$. Only five of the companies viewed in this study disclose monetary information regarding land in their integrated reports. This reflects back to the low disclosure levels on MM2 and the physical information.

\section{Conclusions}

The study indicated that the overall level of corporate disclosure on land of the mining companies was below average. Although integrated reporting and the following of the GRI guidelines have been recommended for a couple of years in South Africa, it was not reflected in the integrated reports of these mining companies.

Relatively high levels of disclosure were evident in providing information about the operation site owned, leased or managed and descriptions of significant impact on land by mining operations. The study displayed low disclosure levels on items that were part of EN12 which deals with indicating the species affected by the mining operations and the duration of the impact on biodiversity.

The low corporate disclosure levels can be attributed to a number of reasons. Corporate disclosure is supposed to be market driven; and as environmental impacts are unavoidable, enforcing land disclosure by corporation's regulation remains important. However, in South Africa, environmental reporting is based on recommendation and little enforcement on the specifications to be disclosed. Therefore, the low levels of disclosure of land information can be attributable to ineffective regulatory systems. The regulatory systems referred to here are not just those directly relating to reporting on land, rather they include regulations that impact indirectly on environmental disclosure, including training regulators, professional accounting bodies as well as the companies and related enforcement mechanisms.

The study found that the mining companies did disclose environmental issues in their integrated report, but their disclosure is limited and/or selective. Based on the above statement and findings, it can be concluded that mining companies do not fully take accountability for the land at their disposal, and this is based on the low levels of disclosure in the sector-specific MM1 and MM2.

\section{References}

Association of Certified Chartered Accountants (ACCA). (2014). Net positive natural capital ambitions: Views and opinions from the ACCA global forum for sustainability. Retrieved June 6, 2016, from http://www.accaglobal.com/content/dam/acca/global/PDF-technical/sustainability-reporting/tech-tp-npnca.pdf

ACCA, Flora \& Fauna International (FFI), and Klynved Peat Marwick Goerdeler (KPMG). (2012). Is natural capital a material

$\begin{array}{lllll}\text { issue. } & \text { Retrieved June } & \text { 2016, from }\end{array}$

http://www.accaglobal.com/content/dam/acca/global/PDF-technical/environmental-publications/natural-capital.pdf

AccountAbility. (2013). Redefining materiality II: Why it matters, who's involved, and what it means for corporate leaders and

boards. $\quad$ Retrieved June $\quad 15, \quad 2016 \quad$ from

http://www.csrwire.com/press_releases/35986-AccountAbility-Releases-a-Report-on-Materiality-Redefining-Materiality-II-

Why-It-Matters-Who-s-Involved-and-What-it-Means-for-Corporate-Leaders-and-Boards-

Betianu, L. J., \& Briciu, S. (2010). The impact of the economic crisis on environmental costs. Romania: Alexandru Ioan Cuza University of Iasi. 
Bishop, J. (2010). The economics of ecosystems and biodiversity in business and enterprise. Retrieved from http://www.teebweb.org/wp-content/uploads/Study\%20and\%20Reports/Reports/Business\%20and\%20Enterprise/TEEB\%20f or\%20Business\%20Report/TEEB\%20for\%20Business.pdf

Bonner, J., Grigg, A., Hime, S., Hewitt, G., Jackson, R., \& Kelly, M. (2012). Is natural capital a material issue? London, UK: ACCA, Flora and Fauna International and KPMG LLP.

Brand, F. (2009). Critical natural capital revisited: Ecological resilience and sustainable development. Ecological Economics, 68, 605-612.

Brundtland Report. (1987). Brundtland report: Our common future. Retrieved June 10, 2016, from http://www.dac.dk/en/dac-cities/sustainable-cities/historic-milestones/1987--brundtland-report-our-common-future/

Constanza, R., \& Daly, H. E. (1992). Natural capital and sustainable development. Conserve Biological Systems, 6, 37-46.

Corporate EcoForum. (2012). The new business imperative: Valuing natural capital. The Nature Conservancy. Retrieved from http://www.corporateecoforum.com/valuingnaturalcapital/offline/download.pdf

Deloitte. (2012). Integrated reporting: Navigating your way to a truly integrated report (2nd ed.). Johannesburg: Deloitte \& Touche.

Eccles, R. G., \& Armbrester, K. (2011). Two disruptive ideas combined: Integrated reporting in the Cloud. IESE Insight, 8, 13-20.

Eccles, R. G., \& Krzus, M. P. (2010). One report: Integrated reporting for a sustainable strategy. New Jersey: John Wiley \& Sons, Inc.

Ekins, P. (2001). From green GNP to the sustainability gap: Recent developments in national environmental economic accounting. Journal of Environmental Assessment Policy and Management, 3(1), 61-93.

Elliott, L. (2004). Global environmental governance: Democratization and local voices. In The global politics of the environment (pp. 113-136). New York: New York University Press.

Ernest and Young. (2013). Excellence in corporate reporting: A survey of annual reports from South Africa's top 100 companies and top 10 state-owned entities. South Africa: Ernest and Young.

Fisher-Kowalski, M. (2011). Analysing sustainability transitions as a shift between socio-metabolic regimes. Environmental Innovation and Societal Transitions, 1, 152-159.

Glazewski, J. (2005). Environmental law in South Africa (2nd ed.). LexisNexis: Durban, South Africa.

Global Reporting Initiative (GRI). (2011). Sustainability reporting guidelines 3.1. Amsterdam: GRI.

Global Reporting Initiative (GRI). (2013). Sustainability reporting guidelines on economic, environmental and social performance. Amsterdam: Kluver Academic.

Goodwin, N. R. (2003). Five kinds of capital: Useful concepts for sustainable development. Working Paper No. 03-07, Global Development and Environment Institute.

Gray, R. (2006). Social, environmental and sustainability reporting and organisational value creation? Whose value? Whose creation? Accounting, Auditing \& Accountability Journal, 19(6), 793-819.

Gray, R. (2012). Integrated reporting: Integrated with what and for whom? The Loop: Safety, Environment \& Quality Management (SEQM). Retrieved from http://theloop.seqm.com/2012/02/13/integrated-reporting/

Houdet, J., \& Germaneau, C. (2011). The financial implications of BP's response to Deepwater Horizon Oil Spill: Comparing damage valuation approaches \& highlighting the need for more reliable environmental accounting and reporting. Retrieved from http://synergiz.fr/wp-content/uploads/2011/04/Case-study-BP-gulf-oil.pdf

International Council on Mining and Metals (ICMM). (2006). Good practice guidance for mining and biodiversity. London: ICMM.

Institute of Directors of South Africa (IoDSA). (2009). SAIGR Wetgewinghandboek: The King III Report and Code on Governance in South Africa (Vol. 3). Durban: LexisNexis.

IoDSA. (2012). Practice notes: The integrated report. Retrieved June 10, 2016, from http://www.iodsa.co.za/PRODUCTSSERVICES/KingIIIReportPapersGuidelines/KingReportonCorporateGovernanceinSA/ KingIIIPracticeNotes.aspx

Integrated Reporting Committee (IRC). (2011). Framework for integrated reporting and the integrated report: Discussion paper. Integrated Reporting Committee of South Africa. Retrieved June 14, 2016, from https://www.saica.co.za/TechnicalInformation/SustainabilityandIntegratedReporting/TheIRCsDiscussionPaper/tabid/2372/la nguage/en-za/Default.aspx

Integrated Reporting Committee of South Africa (IRC of SA). (2011). Framework for Integrated Reporting and the integrated Report. Retrieved from http://integratedreportingsa.org/ircsa/wp-content/uploads/2017/05/IRC-of-SA-Integrated-Reporting-Guide-Jan-11.pdf 
International Integrated Reporting Committee (IIRC). (2011). Towards integrated reporting: Communicating value in the 21st century. Retrieved from http://integratedreporting.org/wp-content/uploads/2011/09/IR-Discussion-Paper-2011_spreads.pdf

International Integrated Reporting Committee. (2013). The International (IR) Framework. Retrieved from https://integratedreporting.org/wp-content/uploads/2013/12/13-12-08-THE-INTERNATIONAL-IR-FRAMEWORK-2-1.pdf

Ioannou, I., \& Serafeim, G. (2014). The consequences of mandatory corporate sustainability reporting: Evidence from four countries. London: Harvard Business School.

Johannesburg Stock Exchange (JSE). (2010). Best performers 2010. JSE and EIRIS. Retrieved June 10, 2016m from http://www.jse.co.za/About-Us/SRI/Results/SRI2010Results.aspx/

JSE. (2011). Best performers 2011. JSE and EIRIS. Retrieved from http://www.jse.co.za/About-Us/SRI/Results/SRI2011Results.aspx

King, M. E. (2011). In Integrated Reporting Committee (IRC) Framework for integrated reporting and the integrated report: Discussion paper. Integrated Reporting Committee of South Africa. Retrieved from http://www.sustainailitysa.org

Kotzé, L. J. (2009). Environmental governance. In A. Paterson and L. J. Kotzé (Eds.), Environmental compliance and enforcement in South Africa: Legal perspectives (pp. 103-125). Claremont, South Africa: Juta Law.

KPMG. (2012). Integrated reporting: Performance insight through better business reporting (Issue 2). Retrieved from http://www.kpmg.com/integratedreporting

Maxwell, D., Mckenzie, E., \& Traldi, R. (2014). Valuing natural capital in business. Taking stock: Existing initiatives and applications. $\quad$ Retrieved from https://www.researchgate.net/publication/269408502_Valuing_natural_capital_in_business_Taking_stock_Existing_initiativ es_and_applications

Natural Capital Declaration (NCD). (2013). The natural capital declaration roadmap: Implementing the four commitments of natural capital declaration. Retrieved from https://www.unepfi.org/fileadmin/documents/ncd_roadmap.pdf

Organisation for Economic Co-operation and Development (OECD). (2007). Glossary of statistical terms. Retrieved from http://stats.oecd.org/glossary/detail.asp?ID=1730

PostNote. (2011). Natural capital accounting, $376 . \quad$ Retrieved from https://www.parliament.uk/documents/post/postpn_376-natural-capital-accounting.pdf

PricewaterhouseCoopers (PwC). (2013). The value creation journey: A survey of JSE Top-40 companies' integrated reports. Retrieved from https://www.pwc.co.za/en/assets/pdf/integrated-reporting-august-2013.pdf

$\begin{array}{llllllll}\text { Protected Areas } & \text { Act } & \text { No } & 57 & \text { of } & 2003 . & \text { (2003). } & \text { Retrieved }\end{array}$ https://www.environment.gov.za/sites/default/files/legislations/nema_amendment_act57.pdf

Solomon, J. F., \& Solomon, A. (2006). Private social, ethical and environmental disclosure. Accounting, Audit and Accountability Journal, 19(4), 564-591.

Szekely, F., \& Knirsch, M. (2005). Leadership and corporate responsibility: Metrics for sustainable corporate performance. Berlin: School of Management and Technology.

TEEB. (2010). The economics of ecosystems and biodiversity. Report for Business, Executive Summary, Authorship. Retrieved June 3, 2016, from http://www.commonland.com/en/file/download/129

Trucost. (2013). Natural capital at risk: the top 100 externalities of business. Retrieved from https://www.trucost.com/publication/natural-capital-risk-top-100-externalities-business/

United Nations. (2012). Resilient people, resilient planet: A future worth choosing (66th session). New York: U.N. General Assembly.

United Nations Environment programme (2016). Natural capital assessments at the national and sub-national level. A guide for Environmental practitioners. Retrieved from https://www.unep-wcmc.org/system/dataset_file_fields/files/000/000/377/original/Natural_Capital_Report_WEB.pdf?14601 19504

Van Zyl, A. S. (2013). Sustainability and integrated reporting in the South African corporate sector. International Business \& Economics Research Journal, 12(8), 903-926.

Visser, W. (2011). The age of responsibility: CSR 2.0 and the new DNA of business. Journal of Business Systems, Governance and Ethics, 5(3), 7-22. 